\title{
KESESUAIAN WAKTU PEMBERIAN OBAT HEMODIALISA DI RSUD A.W SJAHRANIE SAMARINDA
}

\author{
Nur Anggreani*, Rolan Rusli, Nurul Annisa \\ Laboratorium Penelitian dan Pengembangan FARMAKA TROPIS \\ Fakultas Farmasi Universitas Mulawarman, Samarinda, Kalimantan Timur \\ *email : Anggreaninur4@gmail.com
}

\begin{abstract}
ABSTRAK
Hemodialisa didefinisikan sebagai pergerakan larutan dan air dari darah pasien melewati membran semipermeabel (dialyzer) ke dalam dialysate. Pemberian obat pada penyakit hemodialisa ditinjau berdasarkan kesesuaian obat (terdialisis atau tidak) serta waktu pemberian obat (sebelum atau sesudah hemodialisis). Tujuan dari penelitian ini mengetahui kesesuaian obat pada pasien dengan hemodialisis. Studi ini merupakan penelitian observasi dan data disajikan secara deskriptif. Hasil penelitian menunjukkan bahwa obat-obatan yang pemberiannya sesuai adalah amlodipine, calos, amoxicilin, dan isosorbit dinitrat. Obat-obatan yang tidak sesuai pemberiannya adalah asam folat, diazepam, valsartan, tramadol dan furosemide.
\end{abstract}

Kata Kunci : Hemodialisa, Kesesuaian Obat

\begin{abstract}
Hemodialysis as the air and blood circulation of the patient's blood passes through the semipermeable membrane (dialyzer) into the dialysate. The administration of drugs in hemodialysis disease is evaluated according to drug suitability (dialysis or not) and timing of drug administration (before or possibly hemodialysis). The purpose of this study is the suitability of drugs in patients with hemodialysis. This study is an observational study and the data are presented descriptively. The results showed that the drugs that gave it were amlodipine, calos, amoxicilin, and isosorbit dinitrate. Drugs that do not fit the price are folic acid, diazepam, valsartan, tramadol and furosemide.
\end{abstract}

Keywords: Hemodialysis, Drug Compliance

\section{PENDAHULUAN}

Perkembangan teknologi yang semakin pesat memberikan hasil yang positif dalam berbagai bidang, termasuk bidang kesehatan untuk memenuhi kebutuhan 
kesehatan pasien yang lebih baik. Salah satu teknologi yang berkembang di bidang kesehatan adalah terapi yang digunakan untuk memebantu paisen dengan gangguan fungsi ginjal yang terdiri dari hemodialisa, peritoneal dialisa dan transplantasi ginjal. Hemodialisa merupakan terapi pembersih ginjal yang paling banyak dilakukan dan jumlahnya dari tahun ke tahun terus meningkat. Dialysis atau hemodialisa merupakan suatu proses yang digunakan untuk mengeluarkan cairan dan produk-produk sisa metabolisme yang tidak terpakai dari dalam tubuh ketika ginjal sudah tidak mampu lagi berfungsi dengan baik sesuai fungsinya (Smeltzer \& Bare, 2008).

Penurunan fungsi ginjal mengharuskan pasien menjalani terapi hemodialisa sepanjang hidupnya. Biasanya pasien melakukan 2 - 3 kali seminggu selama 3 - 4 jam per sekali terapi hemodialisa (HD). Proses ini menjadi salah satu pilihan bagi pasien penyakit gagal ginjal tahap akhir untuk mempertahankan fungsi ginjal. Pasien dengan terapi hemodialisa mengalami perubahan pada beberapa aspek kehidupannya sehingga mengakibatkan pasien dengan gagal ginjal kronik harus mendatangi unit hemodialisa secara rutin 2-3 kali seminggu, konsisten terhadap obat-obatan yang harus dikonsumsinya, memodifikasi dietnya secara besarbesaran, mengatur asupan cairan hariannya, serta mengukur keseimbangan (balance) cairan setiap harinya, penurunan hemoglobin, pengaturan kalium, kalsium, zat besi dan lain-lain. Kondisi ini menjadi beban berat bagi pasien yang menjalani terapi hemodialisa dan memberikan dampak pada kesehatan pasien, termasuk masalah psikososial dan ekonomi yang mengakibatkan pasien menjad, cemas, stress, ketakutan, depresi sehingga menimbulkan peluang kegagalan terapi dan memperburuk kondisi pasien (Kim, 2010).

Faktor lainnya yang berkontribusi pada kesuksesan ataupun kegagalan terapi hemodialisa adalah kesesuaian pemilihan obat untuk pasien. Tidak sesuainya pemberian obat pada pasien dapat terjadi seperti obat yang diberikan benar, label atau etiket harus dibaca dengan teliti setiap akan memberikan obat. Pemberian obat dalam jangka waktu panjang berpotensi menimbulkan kesalahan pemebrian obat. Sifat obat dapat menimbulkan kesalahan dalam pemebrian obat. Dokumentasi pemberian obat merupakan aspek penting dalam sarana evaluasi (Kamerrer, 2007). 
Oleh karena itu penting untuk mengetahui kesesuaian waktu pemberian dengansifat fisikokimia obat dalam rangka meningkatkan efikasi penggunaan obat.

\section{METODE PENELITIAN}

\section{Alat dan Bahan Penelitian}

Kartu rekam medik pasien dan lembar pengumpul data.

\section{Prosedur Penelitian}

Sebanyak 19 data rekam medik pasien penderita penyakit gagal ginjal kronis yang menjalankan cuci darah atau hemodialisa yang berada di instalasi rawat jalan di RSUD Abdul Wahab Sjahranie yang masuk dalam kriteria inklusi dianalisis secara deskriptif. Data pasien diolah dalam bentuk persentase dan disajikan dalam bentuk tabel atau diagram untuk diperoleh kesimpulan.

\section{HASIL DAN PEMBAHASAN}

\section{Gambaran karakteristik pasien hemodialisa}

Gambaran distribusi pasien hemodialisa berdasarkan usia, jenis kelamin, jumlah obat yang diberikan, dan kelas terapi obat disajikan dalam Tabel 1.

Berdasarkan Tabel 1, responden terbanyak yaitu usia (18-60) tahun. Gagal ginjal kronis semakin banyak menyerang pada usia dewasa muda. Hal ini dikarenakan pola hidup yang tidak sehat seperti banyaknya mengkonsumsi makanan cepat saji, kesibukan yang membuat stres, duduk seharian di kantor, sering minum kopi atau minuman berenergi, jarang mengkonsumsi air putih serta kebiasaan merokok. Kebiasaan kurang baik tersebut menjadi faktor risiko kerusakan pada ginjal (Dharma, 2015). Pada usia >60 tahun, terjadi penurunan laju filtasi glomerulus yang menyebabkan kerusakan fungsi ginjal dan mengharuskan pasien menjalankan terapi hemodialisa (Smeltzer \& Bare, 2008).

Berdasarkan Tabel 1, juga dapat diketahui bahwa laki-laki lebih banyak menjalani HD dibandingkan dengan perempuan. Prevalensi terjadinya gagal ginjal kronik lebih banyak terjadi pada perempuan, sedangkan prevalensi terjadinya ESRD lebih banyak terjadi pada laki-laki. Laki-laki penderita gagal ginjal kronik memiliki resiko yang besar untuk mendapatkan terapi pengganti fungsi ginjal 
dibandingkan perempuan. Peran hormon seksual dalam proses patogenesis kerusakan ginjal mendapatkan banyak perhatian. Dari beberapa penelitian pada hewan diketahui bahwa testosteron berhubungan dengan perkembangan kerusakan ginjal melalui beberapa mekanisme. Hal ini yang menyebabkan perkembangan gagal ginjal kronik pada laki-laki lebih pesat jika dibandingkan dengan perempuan (Daugirdas, 2007). Level hormon testosteron dapat merusak ginjal. Pada laki-laki, gagal ginjal kronik berhubungan dengan rendahnya level hormon testosteron, prolaktin, dan hormon anti-Mullerian, dan tingginya hormon gonadotropin (Gunatillake, 2011).

Tabel 1 Distribusi Karakteristik Responden Hemodialisa

\begin{tabular}{lc}
\hline Karakteristik & Jumlah \\
\hline Usia & \\
\hline (18-60) tahun & 15 tahun \\
$(>60)$ tahun & 4 tahun \\
\hline Jenis Kelamin & 10 orang \\
\hline Laki-laki & 9 orang \\
Perempuan & \\
\hline Jumlah Obat & 3 orang \\
\hline 2 obat & 15 orang \\
3 obat & - \\
4 obat & 1 orang \\
5 obat & \\
\hline Kelas Terapi Obat & 17 orang \\
\hline Antihipertensi & 1 orang \\
Antidiabetes & 2 orang \\
Antibiotik & 2 orang \\
Analgesik & 15 orang \\
Vitamin & 15 orang \\
Osteoforosis & \\
\hline
\end{tabular}

Berdasarkan jumlah dan kelas tearapi obat yang diberikan pada paien hemodialisa, menunjukkan bahwa obat terbanyak digunakan pasien HD yaitu 3 jenis obat berupa obat antihipertensi untuk mengkontrol tekanan darah, vitamin B9 untuk meningkatkan sel darah merah serta kalsium karbonat untuk mengatasi nyeri 
pada saat proses hemodialisa. Pengobatan komplikasi penyakit pada responden hemodialisa sangat penting dilakukan karena pada umumnya gagal ginjal kronik timbul karena komplikasi penyakit. Tujuan pengobatan komplikasi penyakit adalah mencegah dan mengatasi komplikasi penyakit karena jika komplikasi penyakit pasien tidak diatasi dapat meningkatkan kerusakan pada fungsi ginjal. Komplikasi penyakit pada responden HD di RSUD AWS antar lain hipertensi, diabetes mellitus, hiperurisemia, gangguan jantung, infeksi, alergi, dan asma.

Hipertensi pada responden HD diterapi dengan pemberian obat-obat amlodipine dan valsartan. Diabetes mellitus pada responden HD diterapi dengan pemberian hormon insulin dan obat oral furosemid. Amoxcilin digunakan sebagai antibiotik untuk mengobati infeksi yang terjadi. Vitamin B9 diberikan untuk meningatkan sel darah merah didalam tubuh, serta kalsium karbonat digunakan untuk meningkatkan massa tulang, analgesik diberikan diazepam, isosorbit dinitrat, serta tramadol. Masalah yang sering terjadi adalah nyeri, alergi, syok, edema. Tekanan darah umumnya menurun dengan dilakukannya ultrafiltrasi (UF) atau penarikan cairan saat HD. Hipotensi intradialitik terjadi pada 20-30\% penderita yang menjalani HD reguler. Gangguan hemodinamik saat HD juga bisa berupa peningkatan tekanan darah. Dilaporkan sekitar 5-15\% dari pasien yang menjalani HD reguler tekanan darahnya justru meningkat saat HD (Agarwal and Light, 2010).

\section{Gambaran Kesesuian Waktu Pemberian Obat}

Kesesuaian pemberian obat setelah atau sebelum hemodialisa dianalisis berdasarkan karakteristik obat apakah terdialisis atau tidak terdialisis. Sifat dari suatu obat juga menentukan apakah obat tersebut dapat melewati proses hemodialisa atau tidak. Kesesuaian pemberian obat pada pasien Hemodialisa di RSUD disajikan pada Tabel 2.

Penggunaan obat-obatan tertentu dapat menyebabkan gangguan terhadap fungsi ginjal. Diantaranya adalah penggunaan obat-obat antihipertensi, antibiotik, dan AINS pada penderita gagal ginjal. Obat antibiotik dan AINS merupakan obatobat yang sering digunakan dalam penyembuhan penyakit yang diderita banyak 
orang. Kedua obat ini penggunaannya perlu diperhatikan karena dapat menyebabkan nefrotoksisitas pada ginjal (Kenward dan Tan, 2003).

Tabel 2 Kesesuaian Pemberian Obat

\begin{tabular}{cccc}
\hline \multirow{2}{*}{ Nama Obat } & \multirow{2}{*}{ Sifat Terdialisis } & \multicolumn{2}{c}{ Kesesuaian } \\
\cline { 3 - 4 } & & Sesuai (\%) & Tidak Sesuai (\%) \\
\hline Amlodipine & Tidak Terdialisis & 100 & - \\
Amocixilin & Tidak Terdialisis & 100 & - \\
Calos & Tidak Terdialisis & 100 & - \\
Isosorbit Dinitrat & Tidak Terdialisis & 100 & - \\
Asam Folat & Terdialisis & - & 100 \\
Diazepam & Terdialisis & - & 100 \\
Furosemide & Terdialisis & - & 100 \\
Tramadol & Terdialisis & - & - \\
Valsartan & Terdialisis & 100 &
\end{tabular}

Berat molekul zat yang lebih besar tidak dapat menyebrangi membran peritoneal yang kecil, jadi semakin besar bentuk molekul suatu obat maka semakin susah untuk melewati membran. Ikatan protein yang tinggi akan memiliki konsentrasi plasma yang tidak terikat, ketersediaannya sedikit untuk dialysis, jadi semakin tinggi ikatan protein suatu obat makan obat tersebut tidak dapat melewati membran.

Obat dengan volume distribusi besar kemungkinan akan sedikit didialisis. Dan bioavabilitas obat sesuai dengan tinggat penyerapan obat tersebut. Setelah dilihat dari sifat obatnya maka dapat diketahui obat yang terdialisis yaitu obat yang tidak dapat melewati membran semipermeabel pada saat proses hemodialisa dan obat yang tidak terdialisis yaitu obat yang dapat melewati member semipermeable (Sefer Acta Clin S. dan Kroasia Degoricija, 2003). Ini menunjukkan apabila obatobat yang bersifat terdialisis diberikan sebelum hemodialisa maka obat tersebut sesuai dan dapat berefek, apabila diberikan setelah hemodialisa maka obat tersebut akan terbuang pada proses hemodialisa. Hasil yang didapat bahwa pada responden meminum obat bersifat terdialisis sebelum melakukan HD dikatakan sesuai waktu pemberiannya, responden yang meminum obat bersifat tidak terdialisis sebelum 
melakukan HD dikatakan sesuai. Sedangkan responden yang meminum obat bersifat terdialisis setelah melakukan HD dikatakan tidak sesuai, responden yang meminum obat tidak terdialisis setelah melakukan HD dikatakan sesuai. Pada obatobat besifat tidak terdialisis yaitu dimana obat-obat ini dapat melewati membrane semipermeable dan masuk kembali melalui peredaran darah. Obat-obat yang bersifat terdialisis kemungkinan akan terbuang pada proses hemodialisa. Obatobatan yang sesuai yaitu amlodipin, kalsium karbonat, amoxicilin, isosorbit dinitrat. Sedangkan obat yang tidak sesuai yaitu asam folat, tramadol, diazema, furosemid, valsartan.

\section{KESIMPULAN}

Hasil penelitian menunjukkan bahwa obat-obatan yang sesuai pada pemberian obat sebelum dan sesudah hemodialisis adalah amlodipine, calos, amicixilin, dan isosorbit dinitrat, sedangkan obat-obatan yang tidak sesuai pada pemberian obat sebelum dan sesudah hemodialisis adalah asam folat, diazepam, valsartan, tramadol dan furosemide.

\section{DAFTAR PUSTAKA}

Agarwal, R and Light. 2010. Management of Hypertension in Hemodialysis Patients. Hemodialysis international. International Symposium on Home Hemodialysis, 10: 241-248.

Daugirdas, J. T., Blake, P. G. 2007. Handbook Of Dialysis. $4^{\text {th }}$ Edition Philodaphia: Lippincott

Dharma, 2015. Pengantar studi kasus tentang penggunaan obat dan penatalaksanaan penyakit. Yogyakarta : Gre Publising.

Gunatillake, N. D., Javris, E. M., Jakson, D. W. 2011. Hemodialysis Access Infections, Epidemiologi, Pathogenesis and Prevention. INTECH.

Kenward, R., dan Tan, C.K. 2003. Penggunaan Obat Pada Gangguan Ginjal, dalam Aslam Farmasi Klinis: Menuju Pengobatan Rasional dan Penghargaan Pilihan Pasien 2003, 140-153, PT. Elex Media Komputindo Gramedia, Jakarta.

Kim, M. and Kim, Y. 2010. Hypocholesterolemic Effects of Curcumin via Up Regulation of Cholesterol 7a-hydroxylase in Rats Fed a High Fat Diet. Nutrition Research and Practice, 4 (3), 191-195.

Kummer, S. 2012. Buku Ajar Patologi Robbins. Edisi 9. Singapura: Elsevier Saunders. 
Sefer Acta Clin S. dan Kroasia Degoricija. 2003. ABOUT DRUG DIALYZABILITY. Department of Nephrology and Dialysis and University Department of Medicine. 42: 257-267.

Smeltzer et al, 2008. Buku Ajar Keperwatan Medikal Bedah. Jakarta : Buku Kedokteran EGC. 